\title{
Involvement of Peroxisome Proliferator-Activated Receptor- $\alpha$ and $\gamma$ in Apelin Action on the Kidney in Type 2 Diabetic Rat Model
}

\author{
RANDA S. GOMAA, M.D.*; NEVERTYTY M. MAHMOUD, M.D.** and JEHAN SAEED, M.D.*** \\ The Departments of Medical Physiology*, Pharmacology** and Internal Medicine ${ }^{* * *}$, Faculty of Medicine, \\ Zagazig University
}

\begin{abstract}
Background: Apelin is an adipokine that revealed numerous renoprotective actions; however, its effect in diabetic nephropathy is controversial.

Aim of Study: The objectives of the current study were to determine the action of apelin administration on nephropathy in type 2 diabetic rat model and to clarify its possible mechanisms and if PPARs activation is involved in these mechanisms.

Material and Methods: Thirty adult male wistar rats were subdivided into control, diabetic and diabetic-apelin treated rats. Type 2 diabetes was induced via a high-fat diet together with a single low-dose of streptozotocin. Apelin was injected intraperitoneally for 10 weeks. Serum glucose, insulin and lipid profile were estimated. Homeostatic Model Assessment for Insulin Resistance (HOMA-IR) was calculated. Renal functions were evaluated by serum urea and creatinine, urinary albumin excretion, urinary $\mathrm{N}$-acetyl-beta-D-glucosaminidase (NAG) activity and histopathological inspection. Renal tissue homogenate was assessed for Superoxide Dismutase (SOD), Malondialdehyde (MDA), Nitric Oxide (NO) content and PPAR- $\alpha$ and PPAR- $\gamma$ gene expression.
\end{abstract}

Results: Apelin administration to diabetic rats improved hyperglycemia, insulin resistance, dyslipidemia, renal function parameters and pathological lesions in the kidney that resulted from induction of diabetes. It elevates renal SOD and NO, decreased MDA and increased PPAR- $\alpha$ and $\gamma$ gene expression in comparison to diabetic rats.

Conclusions: Apelin administration to diabetic rats improved insulin resistance, hyperglycemia, dyslipidemia and renal functions which may be partially via its antioxidant properties and NO dependent mechanism that struggled the harmful properties of diabetes on the kidney. Besides, apelin induced upregulation of both PPAR $\alpha / \gamma$ genes expression that could be involved in the renoprotective effect of apelin. More investigations for the mechanism by which apelin acts on PPAR $\alpha / \gamma$ are recommended.

Key Words: Apelin - PPARs - Diabetic nephropathy - Oxidative stress.

Correspondence to: Dr. Randa S. Gomaa,

E-Mail: salah_randah@hotmail.com

\section{Introduction}

DIABETIC Kidney Disease (DKD) is a common consequence of Diabetes Mellitus (DM), in which chronic hyperglycemia causes changes of hemodynamic and metabolic pathways that leads to dysfunction of renal and vascular tissues [1]. It constitutes a common public health affair, with a worldwide prevalence of $8-16 \%$ [2].

Apelin; a newly discovered adipocytokine, is an endogenous ligand of seven-transmembrane $G$ protein-coupled receptor APJ [3] that is widely expressed in several tissues, such as heart, lung, kidney, and even tumor tissues [4]. Apelin/APJ system have pleiotropic effects on physiological and pathological processes. It has a protective action in cardiovascular diseases [5] and could control gastrointestinal function, insulin sensitivity and immune function [6]. Recently, it has been postulated that apelin/APJ system plays an essential role in kidney diseases, however, its role in DKD is controversial. It was reported that apelin-13 has a protecting action on the kidney of diabetic mice via antioxidant mechanism [7]. Moreover, direct correlation between apelin levels and the renal function parameter was observed in type 2 diabetic patients, so renal function improves as apelin increases. In addition, apelin is associated with the progress of renal disease as patients with lower apelin levels being more likely to start a depurative technique. This might be related to possible renoprotective role of apelin [8]. On the other hand, apelin administration to kk-Ay mice that is an animal model for Diabetic Nephropathy (DN) induces podocyte dysfunction and promotes DN [9] and increased apelin level in diabetic patients encouraged the progression of DN by inhibiting autophagy in podocytes [10]. 
Peroxisome Proliferator-Activated Receptors (PPARs) are nuclear hormone-activated receptors with three different subtypes that are PPAR- $\alpha$, PPAR- $\beta / \delta$, and PPAR- $\gamma[11]$. PPARs are considered to be critical regulating factor for many biologic processes, as insulin sensitivity, lipid metabolism, immune reactions, and cell growth and differentiation [12]. They have role in the pathogenesis of metabolic syndrome associated diseases including dyslipidemia, atherosclerosis, insulin resistance, hypertension, obesity, and microalbuminuria [13]. The PPAR $\gamma$ agonist thiazolidinediones that used as insulin-sensitizers in the treatment of DM have been confirmed to significantly reduce albuminuria in type 2 diabetic patients [14]. Besides, the fibrate that is anti-hypercholesterolemia therapy has been shown to stimulate PPAR- $\alpha$ and decrease urinary albumin excretion in type 2 diabetic patients [15]. However, the influence of PPARs agonists on renal functions was reported to be a controversial $[\mathbf{1 6 , 1 7 ]}$.

On the other hand, adipokines including apelin might activate different signaling pathways, like AMP-activated protein kinase (AMPK), phosphatidyl inositol 3-kinase/protein kinase B (PI3K/Akt), and PPARs [18].

The objectives of the current study were to determine the action of apelin administration on nephropathy in type 2 diabetic rat model and to clarify its possible mechanisms and if PPARs activation is involved in these mechanisms.

\section{Material and Methods}

\section{Experimental animals:}

A total number of 30 adult male wistar rats aged between 10 and 12 weeks $(200 \pm 20 \mathrm{~g})$ were used as experimental animals in the present investigation and were purchased from Animal House of Faculty of Veterinary Medicine, Zagazig University, Egypt. The animals were housed in standard cages (five rats/cage). They were maintained under controlled room temperature $\left(24 \pm 2^{\circ} \mathrm{C}\right)$ and humidity $(55 \% \pm 5 \%)$ with $12 \mathrm{~h}$ light and $12 \mathrm{~h}$ dark cycle and were fed on a standard diet with free access to water. All experimental procedures and protocols were following the guide for the care and use of laboratory animals ( $8^{\text {th }}$ edition, National Academies Press) and have been reviewed and approved by Zagazig University Institutional Animal Care Unit Committee (ZU-IACUC; Sharkia; Egypt) with approval number: ZU-IACUC/3/F/173/2019.

\section{Experimental protocol:}

Following acclimatization for one week, rats were randomly divided into two groups: Control $(\mathrm{n}=10)$ and experimental $(\mathrm{n}=20)$ groups. Rats in control group were fed normal diet $25 \%$ corn starch, $24.5 \%$ whole wheat flour, $23.3 \%$ refined wheat flour, $20 \%$ soybean meal, $2 \%$ vegetable oil, $2 \%$ fish powder, $1 \%$ calcium bicarbonate, $2 \%$ vitamin and mineral mix, $0.2 \%$ sodium chloride). Experimental rats were fed a high-fat diet containing $66.5 \%$ normal diet, $10 \%$ cow fat, $20 \%$ sucrose, $2.5 \%$ cholesterol, and $1.0 \%$ cholate. Both food formulae were obtained from Faculty of Agriculture, Zagazig University. Both groups had free access to water. After 8 weeks, the experimental rats were given a single intraperitoneal injection of streptozotocin (STZ) $(30 \mathrm{mg} / \mathrm{kg}$, in citrate buffer pH 4.4) (Sigma-Aldrich, St. Louis, MO, USA) [19]. Control animals were injected with equivalent volume of vehicle citrate buffer ( $\mathrm{pH} 4.4 ; 1 \mathrm{ml} / \mathrm{kg}$ ). Seven days following STZ injection, Fasting Blood Glucose (FBG) levels were tested and the rats with high FBG $(\geq 200 \mathrm{mg} / \mathrm{dl})$ were considered to be diabetic rats. The well-established diabetic rats were then randomly divided into two equal subgroups $(n=10)$ : Untreated Diabetes Mellitus (DM) group and diabetic-apelin treated (AP) group. The rats in AP group were received once daily intraperitoneal injection of apelin-13 $(0.1 \mu \mathrm{mol} / \mathrm{kg}$, in saline) (Sigma-Aldrich, St. Louis, MO, USA) for 10 weeks [20]. Both control and diabetic rats were treated with normal saline intraperitoneally. The rats in AP group and DM group were given $\mathrm{HF}$ diet sequentially.

\section{Sample collection and storage:}

At the end of experiment, animals were accommodated in metabolic cage to collect $24 \mathrm{~h}$ urine samples. The urine samples were then centrifuged for $10 \mathrm{~min}$ to remove any debris and stored at $-80^{\circ} \mathrm{C}$. After urine collection all rats were sacrificed after 12 hours of fasting under anesthesia (chloral hydrate) inhalation. Blood samples were obtained by exsanguination at the time of scarification, collected and allowed to clot for 2 hours at room temperature before centrifugation. Sera were stored at $-20^{\circ} \mathrm{C}$ until analysis. Repeated freezing and thawing was avoided. The kidneys were excised from each rat then washed with cold saline. Right kidneys were fixed in $10 \%$ buffered formalin solution at room temperature for histopathological studies. Left kidneys were divided and stored at $-80^{\circ} \mathrm{C}$ under liquid nitrogen for biochemical and gene expression analysis.

\section{Determination of metabolic parameters:}

The sera were examined for level of insulin by ELISA kits (Bio Basic INC, USA) and glucose by enzymatic colorimetric assay using commercial 
kits (Cayman chemicals, USA). The homeostatic model assessment for insulin resistance (HOMAIR) was calculated from the formula: [HOMA-IR = Insulin $(\mathrm{mIU} / \mathrm{L}) \mathrm{X}$ glucose $(\mathrm{mg} / \mathrm{dL}) / 405]$ [21]. For lipid profile assessment, Total Cholesterol (TC), HDL-cholesterol, LDL-cholesterol and Triglycerides (TG) levels using enzymatic colorimetric assays by commercial kits (Spectrum Diagnostics Cairo, Egypt) were examined.

\section{Evaluation of kidney functions:}

Serum urea levels were determined colorimetrically by available commercial kits (Spectrum Diagnostics Cairo, Egypt). Serum and urinary creatinine were determined enzymatically by colorimetric detection using commercial kits (Spectrum Diagnostics Cairo, Egypt). Urinary albumin was measured colorimetrically by rat albumin ELISA kit (Abcam Co. Shanghai, China). Urinary Nacetyl- $\beta$-D-glucosaminidase (NAG) activity was assessed by spectrophotometric determination of the enzymatically released p-nitrophenol from 4nitrophenyl $\mathrm{N}$-acetyl- $\beta$-D-glucosaminide substrate (Cusabio, TX, USA) and the enzyme activity was related to urinary creatinine concentration and expressed as $\mu \mathrm{mol} / \mathrm{h} / \mathrm{mg}$ creatinine.

\section{Determination of renal oxidative stress parameters:}

Kidney tissue was homogenized in $5 \mathrm{~mL}$ cold buffer $(50 \mathrm{mM}$ potassium phosphate $\mathrm{pH} 7.4,1 \mathrm{mM}$ EDTA and $1 \mathrm{~mL} / \mathrm{L}$ Triton X-100). Renal tissue homogenate was assessed for Superoxide Dismutase (SOD) activity and Malondialdehyde (MDA) content using commercially available kits (Bio diagnostic, Cairo, Egypt). SOD activity for assessment of antioxidant activity was measured by modified spectrophotometric assay based on the inhibition of NADH-dependent Nitro-BlueTetrazolium reduction (NBT) by SOD. SOD activity was expressed as U/mg tissue, whereas one unit of enzyme activity is defined as the amount of enzyme that gave $50 \%$ inhibition of NBT reduction in one minute [22]. MDA, for monitoring lipid peroxidation, was evaluated by a method that depends on the reaction between MDA with thiobarbituric acid and the color developed was measured spectrophotometrically. The MDA concentration was expressed as nmol/mg tissue [23].

\section{Determination of renal endothelial function:}

Renal tissue homogenate was assessed for nitric oxide content by colorimetric detection kits (Enzo Life Sciences, Inc. USA), the stable oxidation end products of Nitric Oxide (NO), nitrite and nitrate were measured after the reduction of nitrate to nitrite by copperized cadmium granules. Quantita- tion of nitrite was based on the Griess reaction and the absorbance of developed color was measured spectrophotometrically [24]. The NO concentration was expressed as nmol/mg tissue.

Real-time reverse transcription polymerase chain reaction ( $R T-P C R)$ for the relative quantification of peroxisome proliferator activated receptors (PPAR- $\alpha)$ and (PPAR- $\gamma)$ :

Total RNA was extracted from kidney homogenate by the ribozol RNA extraction reagent (Amresco, Solon, Cleveland, Ohio, USA) as the manufacturer's instructions. cDNAs were synthesized by the SensiFAST TM cDNA synthesis kit (Bioline, London, UK) at $42^{\circ} \mathrm{C}$ for $15 \mathrm{~min}$ then at $85^{\circ} \mathrm{C}$ for $5 \mathrm{~min}$ followed by rapid cooling by ice. Real-time PCR was performed using $10 \mu \mathrm{l}$ of SYBER Green QPCR Mix (SensiFAST TM SYBER Lo-ROX Kit, Bioline London, UK). The SYBER green data were analyzed with a relative quantification to Glyceraldehyde-3-Phosphate Dehydrogenase (GAPDH) as the reference gene. The sets of primers used were as follows:

- PPAR- $\alpha$

- Forward primer: 5'-ACGATGCTGTCCTCCTTGATG-3',

- Reverse primer: 5'-GCGTCTGACTCGGTCTTCTTG-3'

- PPAR- $\gamma$

- Forward primer: 5'-ATTCTGGCCCACCAACTTCGG-3'

- Reverse primer: 5'-TGGAAGCCTGATGCTTTATCCCCA3'

\section{- GAPDH}

- Forward primer: 5'-GTCGGTGTGAACGGATTTG-3'

- Reverse primer: 5'-CTTGCCGTGGGTAGAGTCAT-3'

The relative gene expression ratio is calculated from the real-time PCR by the $2-\Delta \Delta \mathrm{Ct}$ method [25].

\section{Histopathological examination of kidney tissue:}

Kidney samples were fixed in $10 \%$ formalin, paraffin-embedded, cut into 5-micron sections deparaffinized and hydrated in descending series of ethyl alcohol. Sections were stained with hematoxylin $(\mathrm{H})$ and eosin (E) stains, dehydrated and cleared in xylene. The slides were examined blindly by expert pathologist who was blind to the experimental profiles using light microscope (Olympus Electron Microscope, Olympus, Japan) and photographed.

\section{Statistical analysis:}

The results are presented as descriptive statistics (mean \pm standard deviation). Statistical analysis was performed using the Statistical Package for Social Science (SPSS) version 25 (SPSS, Inc., IBM Company, Chicago, IL, USA). The normal 
distribution of data from each group was confirmed using the Kolmogorov-Smirnov normality test. Since the test indicated that variables followed normal distribution, comparisons among the experimental groups were analyzed by one-way analysis of variance (ANOVA) followed by Least Significance Differences (LSD) test to evaluate statistical difference between two groups. $p$-value $<0.05$ was considered to be statistically significant.

\section{Results}

Effect of apelin on glucose metabolism, lipid profile \& renal function:

Induction of diabetes induced significant increase in glucose, HOMA-IR, TG, TC, LDL-C, serum urea and creatinine, urine albumin excretion, and urinary NAG activity with decrease in insulin and HDL-C in DM in comparison to control one $(p<0.001)$. Apelin administration to diabetic rats induced significant decrease in glucose, TG, LDLC $(p<0.001)$, HOMA-IR $(p=0.02)$, TC $(p=0.004)$, serum urea and creatinine $(p<0.001)$ and urinary albumin secretion and NAG activity $(p<0.001)$ with increase in insulin $(p=0.007)$ and HDL-C $(p<0.001)$ when compared with DM group (Table 1).

Table (1): Effect of apelin administration to diabetic rats on glucose metabolism, lipid profile and renal function parameters.

\begin{tabular}{llll}
\hline & Control & \multicolumn{1}{c}{ DM } & \multicolumn{1}{c}{ AP } \\
\hline - Glucose (mg/dL) & $96.8 \pm 6.4$ & $251.9 \pm 15.3^{\mathbf{a}}$ & $211.1 \pm 11.4^{\mathbf{a}, \mathbf{b}}$ \\
- Insulin (mIU/L) & $25.4 \pm 2.7$ & $15.1 \pm 2.3^{\mathbf{a}}$ & $18.8 \pm 3.5^{\mathbf{a}, \mathbf{b}}$ \\
- HOMA-IR & $6.2 \pm 0.7$ & $9.4 \pm 0.8^{\mathbf{a}}$ & $8.9 \pm 0.64^{\mathbf{a}, \mathbf{b}}$ \\
- TG (mg/dL) & $74.7 \pm 5.6$ & $128.5 \pm 11.6^{\mathbf{a}}$ & $87 \pm 9.7 \mathbf{a , b}$ \\
- TC (mg/dL) & $133.4 \pm 9.2$ & $205.8 \pm 24.5^{\mathbf{a}}$ & $182 \pm 10.8^{\mathbf{a}, \mathbf{b}}$ \\
- HDL-C (mg/dL) & $58 \pm 6.7$ & $26.3 \pm 4.5^{\mathbf{a}}$ & $40 \pm 6.7^{\mathbf{a}, \mathbf{b}}$ \\
- LDL-C (mg/dL) & $62.8 \pm 7$ & $150.6 \pm 6.9^{\mathbf{a}}$ & $125.1 \pm 5.2^{\mathbf{a}, \mathbf{b}}$ \\
- Serum urea (mg/dl) & $24 \pm 4.4$ & $52.8 \pm 4.9^{\mathbf{a}}$ & $33.6 \pm 4.3^{\mathbf{a}, \mathbf{b}}$ \\
- Serum creatinine & $0.87 \pm 0.07$ & $3.42 \pm 0.5^{\mathbf{a}}$ & $1.45 \pm 0.39 \mathbf{a , b}$ \\
$\quad(\mathrm{mg} / \mathrm{dl})$ & & & \\
- Urinary albumin & $25.4 \pm 4.4$ & $52.4 \pm 5.7^{\mathbf{a}}$ & $31.8 \pm 6.3^{\mathbf{a}, \mathbf{b}}$ \\
$\quad \begin{array}{l}\text { excretion }(\mathrm{mg} / 24 \mathrm{~h}) \\
\text { - Urinary }(\mathrm{NAG})\end{array}$ & $0.027 \pm 0.006$ & $0.16 \pm 0.03^{\mathbf{a}}$ & $0.057 \pm 0.008^{\mathbf{a}, \mathbf{b}}$ \\
$\begin{array}{l}\text { activity }(\mu \mathrm{mol} / \mathrm{h} / \mathrm{mg} \\
\text { creatinine) }\end{array}$ & & & \\
\hline
\end{tabular}

$\mathrm{n}=10$ in each group.

Data are represented as mean $\pm \mathrm{SD}$.

HDL-C : High-Density Lipoprotein-Cholesterol.

HOMA-IR : Homeostasis Model Assessment-Insulin Resistance.

LDL-C : Low-Density Lipoprotein-Cholesterol.

NAG : N-acetyl- $\beta$-D-glucosaminidase.

TC : Total Cholesterol.

TG : Triglyceride.

Significance $(p<0.05)$ :

(a) Significant when compared with control group,

(b) significant when compared with DM group.

Effect of apelin on renal oxidative stress parameters:

Renal tissue SOD activity was (99.3 \pm 9.2$)$, (71.6 \pm 7.2$) \&(87.9 \pm 6.3) \mathrm{U} / \mathrm{mg}$ tissue and MDA content was $(15.3 \pm 4),(26.3 \pm 6.2) \&(19.4 \pm 3.4)$ $\mathrm{nmol} / \mathrm{mg}$ tissue in control, DM and AP groups respectively.

Induction of diabetes induced significant decrease in renal tissue SOD activity in DM group $(p<0.001)$; with significant increase in renal tissue MDA content in DM group $(p<0.001)$ in comparison to control one. Apelin administration to diabetic rats induced significant increase in renal tissue SOD activity $(p<0.001)$ and significant decrease in MDA content $(p=0.003)$ when compared with DM group Fig. (1).
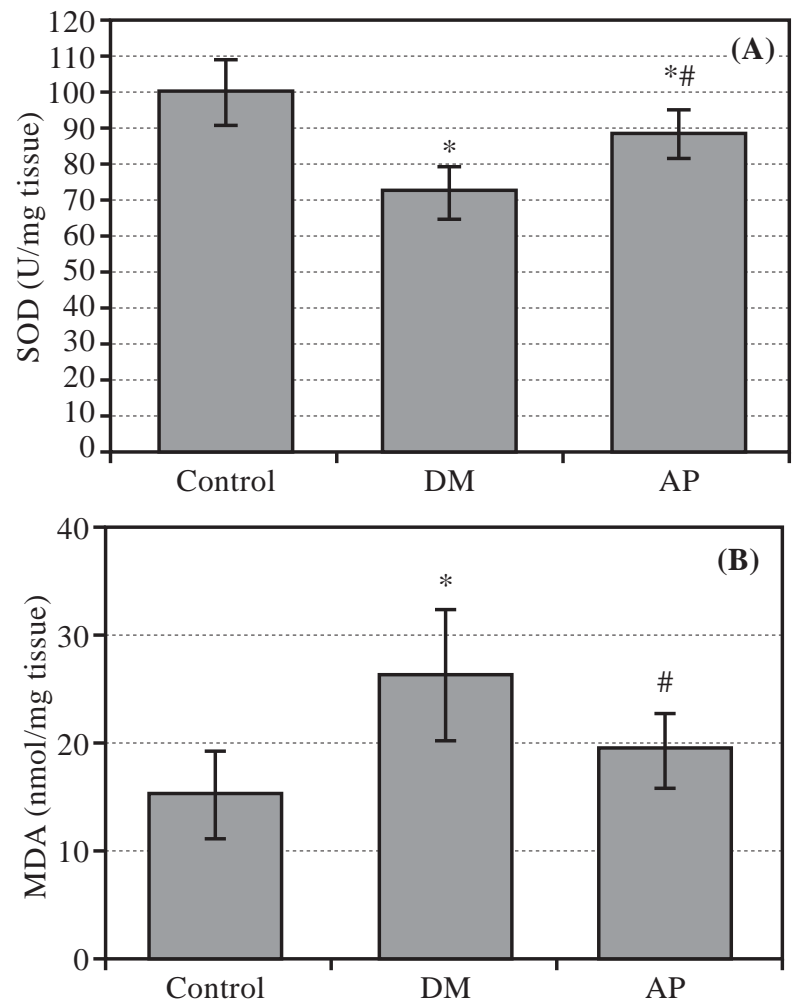

Fig. (1): Effects of apelin on (A) superoxide dismutase (SOD), (B) malondialdehyde (MDA) oxidative parameters in the kidney tissues of diabetic rats.

$\mathrm{n}=(10)$ in each group.

Data are represented as mean \pm standard deviation. Significance $(p<0.05)$ :

(*) Significant when compared with control group.

(\#) Significant when compared with DM group.

\section{Effect of apelin on renal nitric oxide content:}

Renal tissue NO content was (18.2 \pm 3.6$)$, (9.1 \pm 1.85$) \&(12.2 \pm 2.3) \mathrm{nmol} / \mathrm{mg}$ tissue in control, DM and AP groups respectively.

Induction of diabetes induced significant decrease in renal tissue NO in DM group $(p<0.001)$ in comparison to control one while apelin administration to diabetic rats induced significant increase in its level $(p=0.023)$ when compared with DM group Fig. (2). 


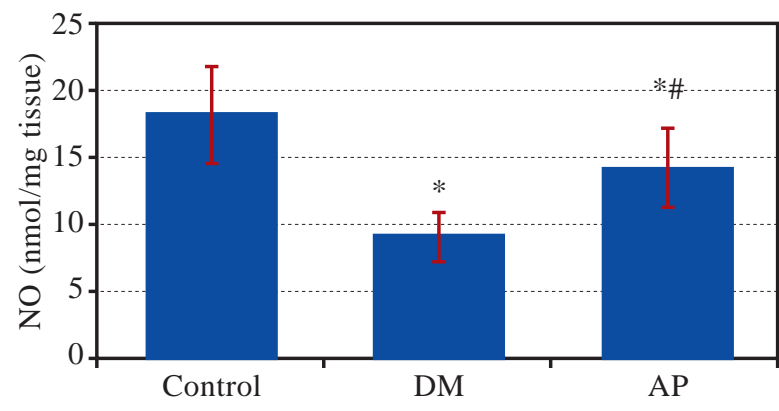

Fig. (2): Effects of apelin on nitric oxide (NO) in the kidney tissues of rats with type 2 diabetes $n=(10)$ in each group.

Data are represented as mean \pm standard deviation. Significance $(p<0.05)$ :

(*) Significant when compared with control group

(\#) Significant when compared with DM group

Effect of apelin on renal PPAR- $\alpha$ and PPAR- $\gamma$ expression:

Relative gene expression of PPAR- $\alpha$ was (3.37 \pm $0.45),(2.23 \pm 0.43) \&(2.65 \pm 0.26)$ and PPAR $-\gamma$ was $(2.43 \pm 0.25),(1.66 \pm 0.35) \&(1.95 \pm 0.26)$ in control, $\mathrm{DM}$ and $\mathrm{AP}$ groups respectively.

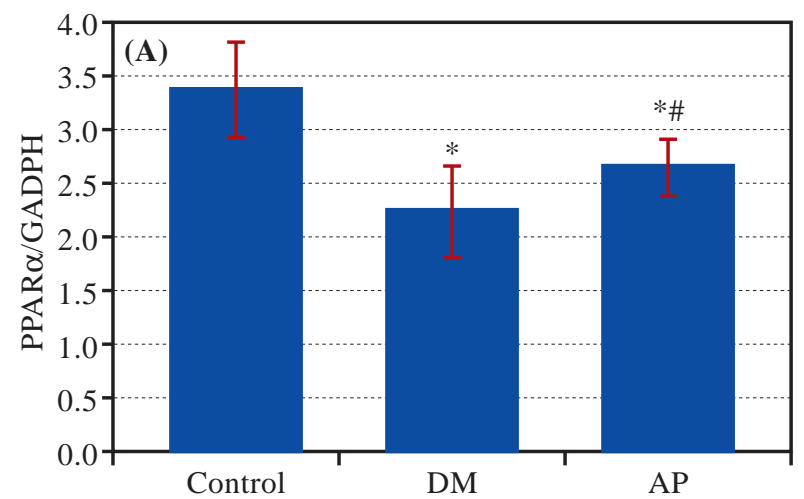

Induction of diabetes induced significant decrease in renal tissue PPAR- $\alpha$ and PPAR- $\gamma$ expression in DM group $(p<0.001)$ in comparison to control one. Apelin administration to diabetic rats induced significant increase in renal tissue PPAR$\alpha$ and PPAR- $\gamma$ expression $(p=0.024, p=0.035)$ when compared with DM group Fig. (3).

\section{Effect of apeline on histopathologcial changes} of kidney in T2DM rats:

Fig. (4) shows the morphology of the glomerulus, as detected by hematoxylin-eosin staining. As compared with kidney sections from control group showed normal histological structure of the glomeruli and renal tubules Fig. (4A). Kidney sections from DM group showed reduced glomerular tuft, increased Bowman's spaces and glomerular hyaline degeneration with vacuolar degeneration, and dilated renal tubules Fig. (4B). On the other hand, kidney sections from AP group showed normal structure of the glomeruli and renal tubule Fig. (4C).

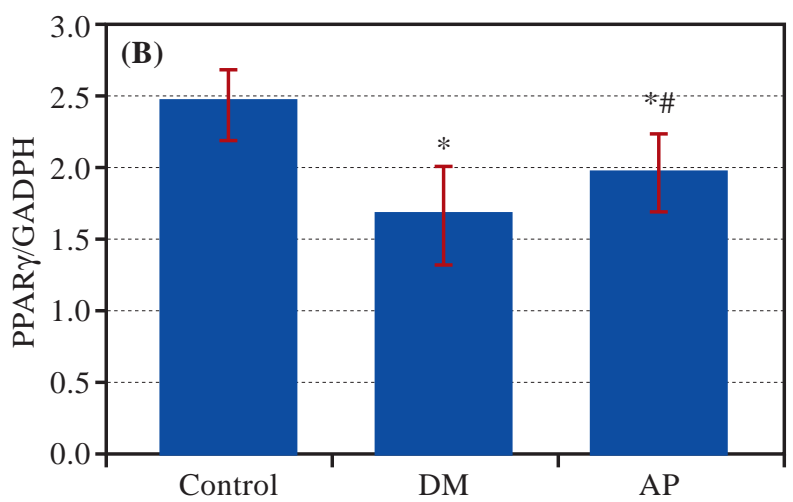

Fig. (3): Effects of apelin on (A) peroxisome proliferator activated receptor- $\alpha$ (PPAR- $\alpha$ ) and (B) peroxisome proliferatoractivated receptor- $\gamma$ (PPAR- $\gamma$ ) in the kidney tissues of diabetic rats. $n=(10)$ in each group.

Data are represented as mean \pm standard deviation

Significance $(p<0.05)$ : (*) Significant when compared with control group, (\#) Significant when compared with DM group.

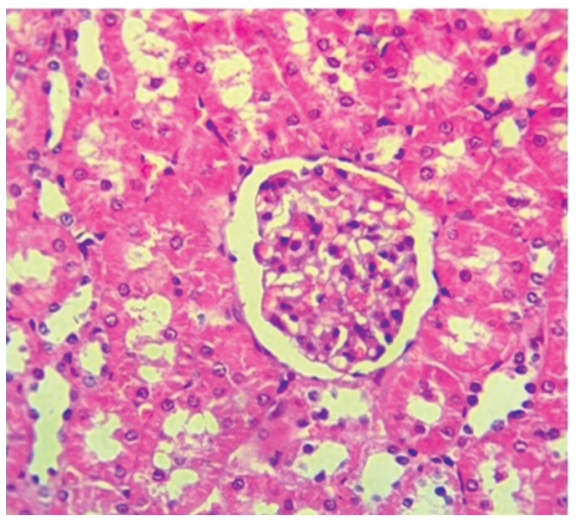

(A)

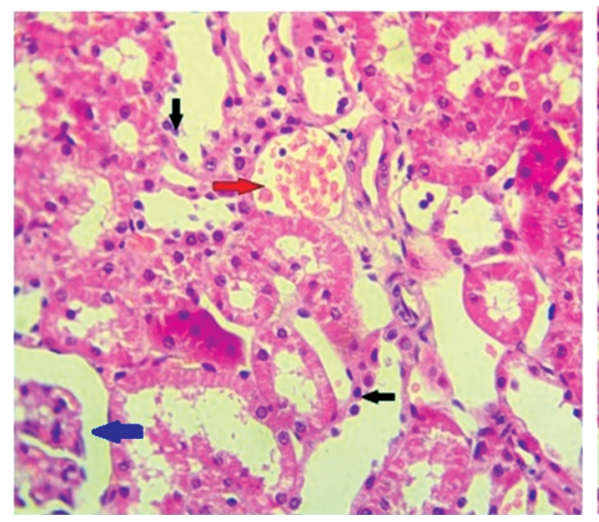

(B)

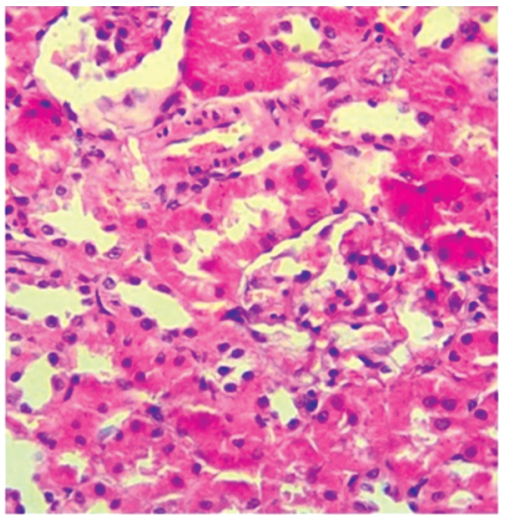

(C)

Fig. (4): Effect of apelin on the histological morphology of type 2 diabetic rat kidneys as detected by hematoxylin and eosin staining. (A) Control, (B) DM rats, (C) Apelin treated diabetic rats (magnification, X400). The histology image showing the normal features of the kidney of the control group Fig. (4A), reduced glomerular tuft, increased Bowman's spaces (blue arrow) glomerular hyaline degeneration (red arrow) with vacuolar degeneration and dilated renal tubules (black arrow) in diabetic rat Fig. (4B). Apelin administration dramatically improved changes in diabetic rats' kidney Fig. (4C). 


\section{Discussion}

In the present study, the action of apelin on kidney was investigated in a high-fat diet, lowdose STZ-induced rat model of T2DM. The results of our study revealed that apelin could lower serum urea and creatinine, decrease urinary NAG activity and improve albuminuria and the renal histopathological lesions in diabetic rats. At the same time, apelin administration to diabetic rats can decrease, glucose levels and insulin resistance, improve insulin level and dyslipidemia, decrease renal tissue MDA and increase SOD activity, NO concentration and PPAR- $\alpha$ and PPAR- $\gamma$ gene expression in renal tissue of diabetic rats.

STZ is widely used to induce diabetes in the experimental animals as it has toxic effects on pancreatic $\beta$-cells as it is employed as glucose analogues that tend to accumulate in pancreatic beta cells through glucose transporter 2 resulting in reduction in blood insulin levels, and hyperglycemia that imitating DM pathology [26]. STZ doses required in DM models remain variable. It was confirmed that high-dose STZ induced direct nephrotoxicity, making it difficult to distinguish between the direct toxic effect of STZ and the lesions resulted from STZ-induced DM [27].

In the current study, insulin resistance was made via a high-fat diet for 8 weeks, followed by a single low dose of STZ $(30 \mathrm{mg} / \mathrm{kg})$ to induce hyperglycemia for one week then the same feeding regimen was continued for 10 weeks to develop diabetes complications in rat model. It has been suggested that diabetic lesion in the kidney is started at least 3 weeks after STZ injection as by this time the kidneys recovered from the acute mild STZ nephrotoxic effects [28].

Kidney damage was assessed in the present study via elevated serum urea and creatinine, albuminuria, increased urinary NAG activity and histological examination of the diabetic kidney. Apelin administration improved the majority of these renal dysfunctions, indicating the nephroprotective properties of apelin in rats with T2DM.

These findings are supported by results of other researches that postulated that apelin treatment defeats diabetes-induced renal histological changes and controls the diabetes-induced renal inflammation and albuminuria [7]. Moreover, apelin could efficiently suppress the progress of nephropathy in Akita mouse, a spontaneous type 1 diabetic model [29]. However, Lui and his colleagues proposed an oppositional opinion that higher apelin level in diabetic kk-Ay mouse that used as a polygenic model for human type 2 diabetes mellitus promoted the progression of renal dysfunction by inducing podocyte dysfunction [10]. Moreover, Guo et al., found that apelin stimulates the progress of DN by inducing podocyte dysfunction and abnormal glomeruli angiogenesis and aggravates albuminuria and glomerular basement membrane thickening in kk-Ay mice [9]. Whether apelin prevents or aggravates the progress of $\mathrm{DN}$ is controversial.

Hyperglycemia is considered to be the main pathological finding of DM and it causes most of diabetic-related complications. Chronic hyperglycemia results in overproduction of Reactive Oxygen Species (ROS) [30] that resulted in damaging cell membranes and inactivating endogenous antioxidants [31]. SOD is one of endogenous antioxidant molecules that counteract ROS-mediated renal injury and it is severely decreased in patients with T2DN [32]. Controlling hyperglycemia remains the major therapeutic strategy as it has a central role in starting the ROS-mediated pathway so this helps the amelioration of oxidative stress [33].

In the current study, hyperglycemia was significantly reduced by apelin demonstrating that controlling hyperglycemia is important for apelinmediated renoprotective effect. Furthermore, SOD and MDA levels in kidney homogenates were determined. In the diabetic group, decreased levels of the SOD was accompanied by an increase in MDA levels. Apelin administration increased renal SOD activity and reduced MDA levels. These results suggested that apelin may exert a renoprotective effect via antioxidant activity.

These data are supported by other studies that proved anti-hyperglycemic action of apelin in diabetic rats [34]. Moreover, Day et al., suggested that renoprotective effects of apelin-13 in diabetic mice could be due to motivation of antioxidant mechanisms [7]. The antioxidant action of apelin is considered to be independent on its antihyperglycemic action as it was reported that apelin13 applied after renal ischemia reperfusion augmented the antioxidant enzyme activity, inhibited the lipid oxidation and enhanced the renal functions in non-diabetic rats [35].

Hyperlipidemia is a common finding with type $2 \mathrm{DM}$ and is known as a risk factor for DN as it may aggravate glomerular injury [36]. It was demonstrated that diabetic dyslipidemia is associated with deterioration in kidney function and albuminuria [37]. In the present study, diabetic rats exhibited 
elevated serum levels of TC, TG and LDL-C, and decreased HDL-C. Apelin administration significantly attenuated these pathological alternations in lipid profile indicating that apelin may improve diabetic effect on the kidney by modulating lipid metabolism and dyslipidemia. These findings are supported by results of a study that investigated effect of apelin on streptozotocin-induced diabetes in male wistar rats that proved its anti-dyslipidemic action [20].

NO should be considered in the pathogenesis of DN, as it plays several functional roles in controlling renal and glomerular hemodynamics [38]. There was evidence suggesting that diabetes affects NO in the kidney by mechanisms that enhance and suppress it at the same time. It has been hypothesized that in early diabetic phases, the equilibrium between these two contrasting forces is shifted to improve NO. As the duration of diabetic exposure increases, factors that reduce NO takes the advantage. Moreover, this balance is affected by actual control of diabetes [39].

In the current study NO level in kidney homogenates was assessed. Diabetes decreased level of the NO while apelin administration to diabetic rats increased its levels. Our results concerning the effect of diabetes on NO was supported by the study that was done on male rats and concluded that renal production of NO is reduced over 12 weeks after development of diabetes [40]. It was reported that renal lesions in ZSF1 rats that represent rat model to study nephropathy from type 2 diabetes are associated with decreased renal NO levels [41]. Moreover, it was reported that agents that stimulate renal NO activity could ameliorate renal injury in streptozotocin-induced diabetic rats [42]. These results supported the hypothesis that apelin could modulate DN via NO dependent mechanism.

PPARs family members are transcription factors that regulate gene expression and play important roles in regulation of lipid metabolism, glucose homeostasis and inflammatory processes [43]. PPAR- $\alpha$ activation corrects dyslipidemia and results in antioxidant and anti-inflammatory action [44] whereas potent PPAR- $\gamma$ activators improve insulin resistance, modulates metabolism and inflammation in immune cells and controls cell proliferation [45]. Moreover, PPAR- $\alpha$ and PPAR- $\gamma$ have been reported to upregulate NO synthase (NOS) and stimulate NO release, that counteract endothelial dysfunction present in patients with T2DM [46]. The expression of PPAR- $\alpha$ and PPAR- $\gamma$ was described in the kidney tissues. They have beneficial role for treating type
2 diabetes with promising renal effects including both systemic and direct renal effects [47].

The data of the current study showed downregulation of renal PPAR- $\alpha$ and PPAR- $\gamma$ in diabetic rats. These results supported by the human study that concluded that PPAR receptors were significantly reduced in diabetic patients [48]. In addition, PPAR- $\gamma$ null mice represented an effective model for studying the initiation and the progress of diabetic nephropathy [49].

Apelin administration to diabetic rats in our study upregulates PPAR- $\alpha$ and PPAR- $\gamma$ gene expression in renal tissue indicating the dual activating action of apelin for PPAR $\alpha / \gamma$. To our knowledge, the effect of apelin on PPARs expression in the kidney of diabetic rat is not previously investigated. However studies on other ligands that have PPAR $\alpha / \gamma$ dual agonistic action found that they improved insulin resistance, hyperglycemia, dyslipidemia and markedly diminished albuminuria and renal glomerular fibrosis in type 2 diabetes $\mathrm{db} / \mathrm{db}$ mice [50].

These findings support the hypothesis that PPAR $-\alpha$ and PPAR $-\gamma$ could be involved in the nephron protective action of apelin in diabetic rats. However, whether apelin directly activate PPAR $\alpha / \gamma$ or activates them via secondary pathways needs more investigations.

We could conclude that apelin administration to diabetic rats improved insulin resistance, hyperglycemia, dyslipidemia and renal functions which may be partially via its antioxidant properties and NO dependent mechanism that struggled the harmful properties of diabetes on the kidney. Besides, apelin induced upregulation of both PPAR $\alpha / \gamma$ genes expression that could be involved in the renoprotective effect of apelin. More investigations for the mechanism by which apelin acts on PPAR $\alpha / \gamma$ are recommended.

\section{Acknowledgements:}

The authors express their gratitude to Dr. Hayam Elsaid Rashed, Assistant Professor of Pathology Department, Faculty of Human Medicine, Zagazig University, Egypt for her help in histopathological assessment.

\section{Conflicts of interest:}

All authors have no conflicts of interest.

Financial support and sponsorship:

Nil. 


\section{References}

1- JHA J.C., BANAL C., CHOW B.S.M., COOPER M.E. and JANDELEIT-DAHM K.: Diabetes and kidney disease: Role of oxidative stress. Antioxid Redox Signal., 25: 657 84, 2016.

2- JHA V., GARCIA-GARCIA G., ISEKI K., LI Z., NAICKER S., PLATTNER B., SARAN R., WANG A.Y. and YANG C.W.: Chronic kidney disease: Global dimension and perspectives. Lancet., 382: 260-72, 2013.

3- LIU C., SU T., LI F., LI L., QIN X., PAN W., FENG F., CHEN F., LIAO D. and CHEN L.: PI3K/Akt signaling transduction pathway is involved in rat vascular smooth muscle cell proliferation induced by apelin-13. Acta Biochim Biophys Sin (Shanghai), 42: 396-402, 2010.

4- HUANG Z., WU L. and CHEN L.: Apelin/APJ system: A novel potential therapy target for kidney disease. J. Cell Physiol., 233: 3892-900, 2018.

5- YU X.H., TANG Z.B., LIU L.J., QIAN H., TANG S.L., ZHANG D.W., TIAN G.P. and TANG C.K.: Apelin and its receptor APJ in cardiovascular diseases. Clin. Chim. Acta., 428: 1-8, 2014.

6- CASTAN-LAURELL I1., DRAY C., KNAUF C., KUNDUZOVA O. and VALET P.: Apelin, a promising target for type 2 diabetes treatment. Trends. Endocrinol. Metab., 23: 234-41, 2012.

7- DAY R.T., CAVAGLIERI R.C. and FELIERS D.: Apelin retards the progression of diabetic nephropathy. Am. J. Physiol. Renal. Physiol., 304: F788-F800, 2013.

8- SILVA A.P., FRAGOSO A., SILVA C., VIEGAS C., TAVARES N., GUILHERME P., SANTOS N., RATO F., CAMACHO A., CAVACO C., PEREIRA V., FAÍSCA M., ATAÍDE J., JESUS I. and NEVES P.: What is the role of apelin regarding cardiovascular risk and progression of renal disease in type 2 diabetic patients with diabetic nephropathy? Biomed. Res. Int., 247649, 2013.

9- GUO C., LIU Y., ZHAO W., WEI S., ZHANG X., WANG W. and ZENG X.: Apelin promotes diabetic nephropathy by inducing podocyte dysfunction via inhibiting proteasome activities. J. Cell Mol. Med., 19: 2273-85, 2015.

10- LIU Y., ZHANG J., WANG Y. and ZENG X.: Apelin involved in progression of diabetic nephropathy by inhibiting autophagy in podocytes. Cell Death Dis., 8: e3006, 2017.

11- BROEDERS N. and ABRAMOWICZ D.: Peroxisome proliferator-activated receptors (PPARs): Novel therapeutic targets in renal disease. Kidney Int., 60: 14-30, 2002.

12- DESVERGENE B. and WAHLI W.: Peroxisome proliferator-activated receptor: Nuclear control of metabolism. Endocr. Rev., 20: 649-88, 1999.

13- WILLSON T.M., LAMBERT M.H. and KLIEWER S.A.: Peroxisome proliferator-activated receptor gamma and metabolic disease. Annu. Rev. Biochem., 70: 341-67, 2001.

14- SARAFIDIS P.A., STAFYLAS P.C., GEORGIANOS P.I., SARATZIS A.N. and LASARIDIS A.N.: Effect of thiazolidinediones on albuminuria and proteinuria in diabetes: A meta-analysis. Am. J. Kidney Dis., 55: 835-47, 2010.

15- SMULDERS Y.M., VAN EEDEN A.E., STEHOUWER C.D., WEIJERS R.N., SLAATS E.H. and SILBERBUSCH
$\mathrm{J} .:$ Can reduction in hypertriglyceridaemia slow progression of microalbuminuria in patients with non-insulindependent diabetes mellitus? Eur. J. Clin. Invest., 27: 997-1002, 1997.

16- SALGUEIRO G., BELTRÁN L.M., TORRES R.J. and PUIG J.G.: Fenofibrate increases serum creatinine in a patient with familial nephropathy associated to hyperuricemia. Nucleosides Nucleotides Nucleic Acids., 33: 1814, 2014.

17- BALAKUMAR P., VARATHARAJAN R., NYO Y.H., RENUSHIA R., RAAGINEY D., OH A.N., AKHTAR S.S., RUPESHKUMAR M., SUNDRAM K. and DHANARAJ S.A.: Fenofibrate and dipyridamole treatments in low-doses either alone or in combination blunted the development of nephropathy in diabetic rats. Pharmacol Res., 90: 36-47, 2014.

18- DUPONT J., REVERCHON M., CLOIX L., FROMENT P. and RAMÉ C.: Involvement of adipokines, AMPK, PI3K and the PPAR signaling pathways in ovarian follicle development and cancer. Int. J. Dev. Biol., 56: 959-67, 2012.

19- ZHANG S., XU H., YU X., WU Y. and SUI D.: Metformin ameliorates diabetic nephropathy in a rat model of lowdose streptozotocin-induced diabetes. Exp. Ther. Med., 14: 383-90, 2017.

20- HEGAB I.I.: Ameliorative effect of apelin on streptozotocin-induced diabetes and its associated cardiac hypertrophy. Alexandria J. Med., 54: 119-27, 2017.

21- SINGH B. and SAXENA A.: Surrogate markers of insulin resistance: A review. World J. Diabetes, 1: 36-47, 2010.

22- KAKKAR P., DAS B. and VISWANATHAN P.N.: A modified spectrophotometric assay of superoxide dismutase. Indian J. Biochem. Biophys., 21: 130-2, 1984.

23- OHKAWA H., OHISHI N. and YAGI K.: Assay for lipid peroxides in animal tissues by thiobarbituric acid reaction. Anal. Biochem., 95: 351-8, 1979.

24- SASTRY K., MOUDGAL R., MOHAN J., TYAGI J. and RAO G.: Spectrophotometric determination of serum nitrite and nitrate by copper-cadmium alloy. Anal. Biochem., 306: 79-82, 2002.

25- VANGUILDER H.D., VRANA K.E. and FREEMAN W.M.: Twenty-five years of quantitative PCR for gene expression analysis. BioTechniques, 44: 619-26, 2008.

26- LENZEN S.: The mechanisms of alloxan-and streptozotocin-induced diabetes. Diabetologia, 51: 216-26, 2008.

27- TAY Y.C., WANG Y., KAIRAITIS L., RANGAN G.K., ZHANG C., and HARRIS D.C.: Can murine diabetic nephropathy be separated from superimposed acute renal failure? Kidney Int., 68: 391-8, 2005.

28- KRAYNAK A.R., STORER R.D., JENSEN R.D., KLOSS M.W., SOPER K.A., CLAIR J.H., DeLUCA J.G., NICHOLS W.W. and EYDELLOTH R.S.: Extent and persistence of streptozotocininduced DNA damage and cell proliferation in rat kidney as determined by in vivo alkaline elution and BrdUrd labeling assays. Toxicol. Appl. Pharmacol., 135: 279-86, 1995.

29- CHEN H., LI J., JIAO L., PETERSEN R.B., LI J., PENG A., ZHENG L. and HUANG K.: Apelin inhibits the development of diabetic nephropathy by regulating histone acetylation in Akita mouse. J. Physiol., 592: 505-21, 2014. 
30- MATOUGH F.A., BUDIN S.B., HAMID Z.A., ALWAHAIBI N. and MOHAMED J.: The role of oxidative stress and antioxidants in diabetic complications. Sultan Qaboos Univ. Med. J., 12: 5-18, 2012.

31- YAN L.J.: Analysis of oxidative modification of proteins. Curr. Protoc. Protein Sci., Chapter, 14: Unit. 14.4, 2009.

32- VOLPE C.M.O., VILLAR-DELFINO P.H., DOS ANJOS P.M.F. and NOGUEIRA-MACHADO J.A.: Cellular death, reactive oxygen species (ROS) and diabetic complications. Cell Death Dis., 9: 119-27, 2018.

33- SHAO N., KUANG H.Y., WANG N., GAO X.Y., HAO M., ZOU W. and YIN H.Q.: Relationship between Oxidant/Antioxidant Markers and Severity of Microalbuminuria in the Early Stage of Nephropathy in Type 2 Diabetic Patients. J. Diabetes Res., 232404, 2013.

34- AKC1LAR R., TURGUT S., CANER V., AKC1LAR A., AYADA C., ELMAS L. and ÖZCAN TO.: The effects of apelin treatment on a rat model of type 2 diabetes. Adv. Med. Sci., 60: 94-100, 2015.

35- BIRCAN B., ÇAK1R M., K1RBA S. and GÜL H.F.: Effect of apelin hormone on renal ischemia/reperfusion induced oxidative damage in rats. Ren. Fail., 38: 11228, 2016.

36- GAI Z., WANG T., VISENTIN M., KULLAK-UBLICK G.A., FU X. and WANG Z.: Lipid Accumulation and Chronic Kidney Disease. Nutrients, 11: 722-42, 2019.

37- BALAKUMAR P., KADIAN S. and MAHADEVAN N.: Are PPAR alpha agonists a rational therapeutic strategy for preventing abnormalities of the diabetic kidney? Pharmacol. Res., 65: 430-6, 2012.

38- LEE J.: Nitric oxide in the kidney: Its physiological role and pathophysiological implications. Electrolyte Blood Press., 6: 27-34, 2008.

39- KOMERS R. and ANDERSON S.: Paradoxes of nitric oxide in the diabetic kidney. Am. J. Physiol. Renal. Physiol., 284: F1121-F1137, 2003.

40- MAHMOUD A.M., ASHOUR M.B., ABDEL-MONEIM A. and AHMED O.M.: Hesperidin and naringin attenuate hyperglycemia-mediated oxidative stress and proinflammatory cytokine production in high fat fed/streptozotocininduced type 2 diabetic rats. J. Diabetes Complications, 26: 483-90, 2012.

41- PRABHAKAR S., STARNES J., SHI S., LONIS B. and TRAN R.: Diabetic nephropathy is associated with oxidative stress and decreased renal nitric oxide production. J. Am. Soc. Nephrol., 18: 2945-52, 2007.
42- ZHOU S.J., BAI L., LV L., CHEN R., LI C.J., LIU X.Y., YU D.M. and YU P.: Liraglutide ameliorates renal injury in streptozotocin-induced diabetic rats by activating endothelial nitric oxide synthase activity via the downregulation of the nuclear factor- $\mathrm{\kappa B}$ pathway. Mol. Med. Rep., 10: 2587-94, 2014.

43- JAY M.A. and REN J.: Peroxisome proliferator-activated receptor (PPAR) in metabolic syndrome and type 2 diabetes mellitus. Curr. Diabetes. Rev., 3: 33-9, 2007.

44- PLUTZKY J.: Preventing type 2 diabetes and cardiovascular disease in metabolic syndrome: The role of PPAR alpha. Diab. Vasc. Dis. Res., 4: S12-4, 2007.

45- WANG L., WALTENBERGER B., PFERSCHY-WENZIG E.M., BLUNDER M., LIU X., MALAINER C., BLAZEVIC T., SCHWAIGER S., ROLLINGER J.M., HEISS E.H., SCHUSTER D., KOPP B., BAUER R., STUPPNER H., DIRSCH V.M. and ATANASOV A.G.: Natural product agonists of peroxisome proliferatoractivated receptor gamma (PPAR $\gamma$ ): A review. Biochem. Pharmacol., 1; 92: 73-89, 2014.

46- GOYA K., SUMITANI S., XU X., KITAMURA T., YAMAMOTO H., KUREBAYASHI S., SAITO H., KOUHARA H., KASAYAMA S. and KAWASE I.: Peroxisome proliferator-activated receptor alpha agonists increase nitric oxide synthase expression in vascular endothelial cells. Arterioscler. Thromb. Vasc. Biol., 24: 658-63, 2004.

47- GUAN Y.: Peroxisome proliferator-activated receptor family and its relationship to renal complications of the metabolic syndrome. J. Am. Soc. Nephrol., 15: 2801-15, 2004.

48- AFZAL N., HASSAN M., FATIMA S., TARIQ S. and QAYUM I.: Expression Of Peroxisome-Proliferator Activated Receptors- $\gamma$ In Diabetics, Obese And Normal Subjects. J. Ayub. Med. Coll Abbottabad., 28: 130-4, 2016.

49- TOFFOLI B., GILARDI F., WINKLER C., SODERBERG M., KOWALCZUK L., ARSENIJEVIC Y., BAMBERG K., BONNY O. and DESVERGNE B.: Nephropathy in Pparg-null mice highlights PPAR $\gamma$ systemic activities in metabolism and in the immune system. PLoS One, 12 (2): e0171474, 2017.

50- CHA D.R., ZHANG X., ZHANG Y., WU J., SU D., HAN J.Y., FANG X., YU B., BREYER M.D. and GUAN Y.: Peroxisome proliferator activated receptor alpha/gamma dual agonist tesaglitazar attenuates diabetic nephropathy in db/db mice. Diabetes, 56 (8): 2036-45, 2007. 


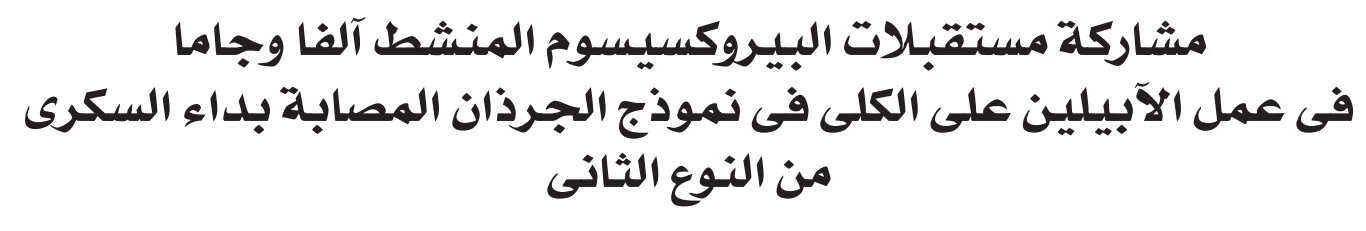

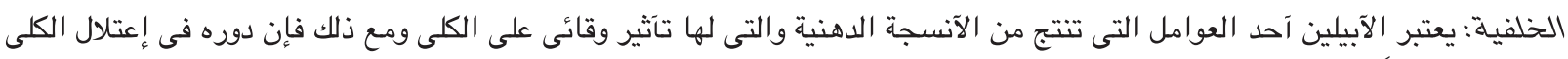

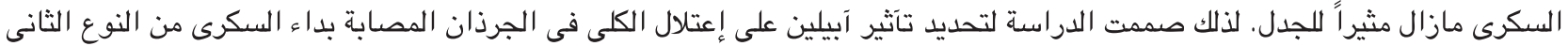
وتوضيح الآليات المحتملة لهذا التآثير وإذا كان تنشيط مستقبلات البيروكسيسوم المنشط في هذه الآليات.

مواد وطرق البحث: شملت الدراسة ثلاثين جرذاً من الذكور البالغة والتى تم تصنيفها إلى ثلاثة مجموعات متساوية كل منها عشرة جرذان: • مجموعة ضابطة. • مجموعة مصابة بداء السكرى من النوع الثانى. مجوع. • مجموعة مصابة بداء السكرى من النوع الثانى مع العلاج بالآبيلين.

تم تقدير تحليل آمصال الدم لكل من قيمة الجلوكوز، الإنسولين، الدهون الثثاثية، الكوليسترول الكلى، البروتين الدهنى عالى الكثافة، البروتين

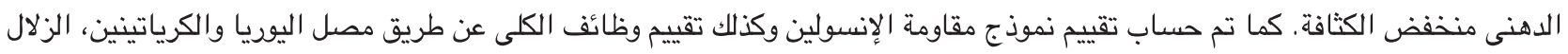

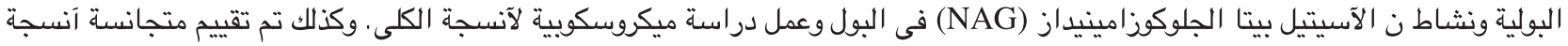

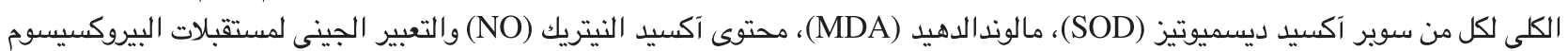

المنشط آلفا وجاما (PPAR- $\gamma_{\text {I }}$ (PPAR-

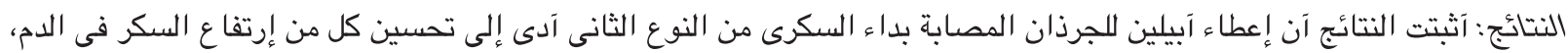

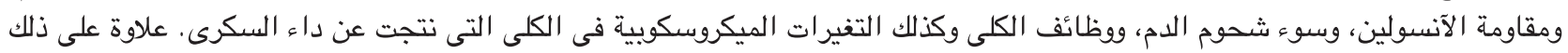

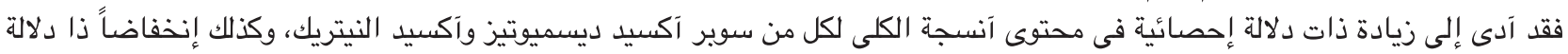

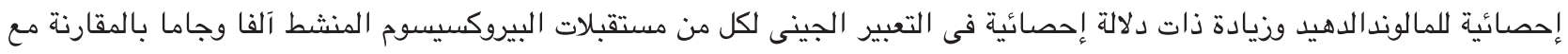
الجرذان المصابة بداء السكرى.

المستخلص من البحث: خلصت هذه الدراسة إلى آن إعطاء آبيلين للجرذان المصابة بداء السكرى من النوع الثانى آدى إلى تحسين كل

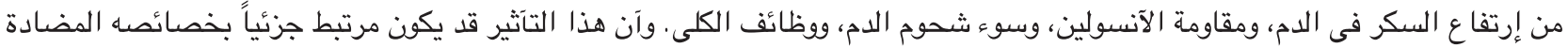

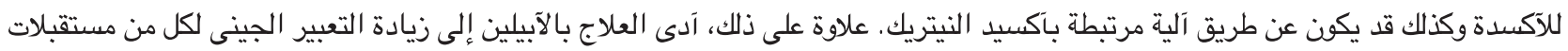



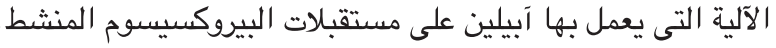

